\title{
Teaching Research on College English from the Perspective of Demand
}

\author{
Xiaowei Bu \\ Xi'an International University, Xi'an , 710077, China
}

\begin{abstract}
Keywords: The perspective of demand, Colleges and Universities, College English, Course teaching
\end{abstract}

\begin{abstract}
With the continuous reform and deepening of the social system, the relationship between our country and other countries is becoming more frequent, so in a globalized environment, the standards of college English teaching have been further improved, and it is wanted that the ways of college English change from popular type into professionalization. Then, from the perspective of demand, to carry on analyse of English teaching, curriculum provision, teaching methods and others, and put forward measures to optimize the quality of college English teaching, so as to provide a reference for the development of colleges and universities.
\end{abstract}

\section{Introduction}

Under the tendency of economic integration, English will permeate all walks of life of society. At the same time, in order to adapt to the development of globalization, the university must strengthen the English teaching, reform the English curriculum, which meets the needs of social development. Therefore, the university must do research about the challenges in English teaching process from the perspective of demand, and analyze the needs of college English teaching, and then take effective measures to optimize the teaching methods, improve the comprehensive strength of English teachers and other ways, in order to make the college English teaching goal compatible with social needs. In short, if colleges and universities want to improve the quality of English teaching, they must carry on analysis from the perspective of demand, so as to make a better development for the students.

\section{Introduction to needs analysis theory}

The so-called demand analysis refers to the process of full analysis and mastering the learners' needs, the scholars believe that the demand is what need to do for English learners to master a language, and whether it is common English or specialized English, in the course of teaching, we must build on the needs of students. For the needs analysis, from the content, mainly includes two aspects, namely learning needs analysis and target demand analysis. Learning needs are mainly to understand the students' language ability before learning English, and investigate the students' language situation and learning preferences, expectations and so on; and target needs analysis refers to that the teachers need to analyze the students' personal learning situation, English ability, and then understand how the students' grasp the English, after the students finish English curriculum.

\section{The concept and classification of college English demands in colleges and universities}

The concept of college English demands refers to study the needs of College English with the use of interviews, questionnaires and other methods, including the acquisition of mathematical information source, intervention time, etc.. In the process of English teaching, the teachers need to combine the actual situation, to evaluate the teaching, and then through the need to develop a more sound teaching plan. In addition, it is also able to adapt college English teaching to the goal and the level of other countries, so that the design and teaching of English courses can achieve good results. So far, the analysis of the demand for college English has been a long time. At first, it is only for analyzing the demands of English for special purpose, after the focus changes,the language demands for the learners will change for learning needs, especially the common English is widely used.. The demand model of college English is divided into four major categories, they are Allwright the model 
of Situation analysis, Munby the model of target situation analysis, Dudley-Evans\&\&St John model and Present Situation Analysis. Under the action of these four models, we can make a research on English needs analysis, curriculum setting and so on, so as to provide a favorable basis for college English teaching [1].

\section{The analysis of instruction requirements of college English in colleges and universities}

\section{Individual demand}

With the continuous reform and improvement of the education system, college English teaching has achieved some results, in order to cultivate more and more compound talents, the students who have rich English knowledge and skills can communicate well with foreign personnel. In the promotion of reform and opening up, the gap between college English teaching and demand is getting more obvious. For individual demand, the students who major in English language are more willing to enter the language in a variety of forms, and learn the content of the authenticity and practical value. At the same time, we also find that students strive to continuously improve their ability of English communication and learning, so as to meet the needs of their own to improve the cultural quality of English. Usually, in order to achieve good results in teaching and complete English teaching goal, in the teaching process, English teachers often make the teaching material as the benchmark, and attach the courseware, resulting that the English teaching is not flexible. According to the investigation and analysis in 2013, the English level of college students dropped to 40\%, the satisfaction of English teaching is less than $60 \%$. In such a low demand condition, college English teaching can not meet the students' learning demands [2].

\section{Society demands}

In the process of analyzing the society demands, at present, there are nearly 300 million people learning English in China, and there are the contents of English curriculum in the education phase of university, middle school and primary school. It is can be seen that the number of English learners has occupied a large part of the national total in China.Concerned expert thought, after a couple of years, the number of English learners will be more than the total number of native speakers in China. However, although many people are learning English in China, the high-end English talent is very scarce, especially the talents of the written translation and simultaneous interpretation are very scarce, even in Beijing, Shanghai and other large cities. In addition, the person of professional and English skills has a certain position in society, it is because that English as an important communication tool, has a strong applicability, however, English is not linked with mechanical, process and other organic, then, the talents of professional and English skills the enterprise needs are relatively scarce.

\section{The challenge for college English teaching under the new situation}

\section{Middle school English has a certain influence on college English}

At present, because middle school English has a certain influence on college English, which results that the college English teaching is confronted with dire challenges under the new situation. With the popularization of English, English teaching transition has been from the middle school to primary school, English teaching has also been infiltrated into primary school. At the same time, in high school, English teaching goal of Standard of high school English course is very clear, the English vocabulary of excellent high school students must reach 4500 words or more, and the English vocabulary of general high school graduate students is more than 3300 words, under the condition of continuous improvement of English teaching level, the number of the students whose level is more than English level of four gradually increased during college period ${ }^{[3]}$. However, the English ability of the students who are non-English major is relatively low, because of the differences of entry level, the enthusiasm of the students poor in English is easy to fall, and the quality of college English teaching should be improved. 


\section{The teaching orientation of college English is inaccurate}

Under the new situation, the college English teaching is confronted with dire challenges, especially the teaching orientation of college English is inaccurate, which results that the teaching effect could not meet the requirements of the society. In the process of English teaching, the modern society requires that we should cultivate talents of professional knowledge and English language skill. However, under the influence of college English language teaching, the teaching orientation of college English is consistent with the teaching orientation of primary English that focus on basic knowledge teaching. It can not be organic connection with profession the major, then result that the students are not rich in professional terms, and can not adapt to the social work, which restricts the development of college English teaching.

\section{The serious effect of testing education}

In the process of teaching, the most of the energy of colleges and universities will be used in the exam-oriented education, which leads to the contradiction between learning pattern and language acquisition. For a long time, every stage of our country's education considers the exam-oriented education as the key content. For example, the purpose of primary school teaching is to make the students successfully into the high school, and the purpose of high school teaching is to make the students successfully into the university, but college students graduation is for what? However, under the influence of exam-oriented education, the students can not apply their English knowledge to all. At the same time, there is no clear requirements of society when the students took the examination of CET4,CET6 and other certificates. In the environment of English exam-oriented education, the students can not enter the language effectively, which leads to the poor English ability.

\section{English course arrangement is to be reformed}

Although the Education Department has carried on the reform of college English teaching in colleges and universities, the key content makes its transition from the training of reading and writing to the ability of listening and speaking, listening speaking reading writing all will be the main content. At the same time, the traditional teaching mode will be changed, the modern multimedia means will be used to carry out the college English teaching, and make the students finish the learning task in the autonomous learning mode. However, there are still many problems in English course arrangement, which results that the students are not able to have a deep understanding of English curriculum contents. Therefore, if the quality of college English teaching is wanted to be improved, it is necessary to set up a reasonable English course, so as to provide a favorable guarantee for the society to develop more and more English majors.

\section{Tn terms of demand, the concrete measures of college English teaching reform from}

\section{Improve the comprehensive ability of English teachers}

In order to adapt the demands, college English teaching must improve the comprehensive ability of English teachers, the students learn a wealth of professional knowledge by improving the level of teaching.. In the process of teaching, teachers must ensure that their ability conforms to the knowledge structure, and continuous access to new English knowledge, especially the content of specialization, so that the practical experience and theory of the teachers are enhanced. In addition, the teacher must strengthen the conception of English for specific purpose, so as to promote better development of students. Therefore, the improvement of the comprehensive ability of English teaching plays an important role in improving the quality of English teaching.

\section{The reasonable design of English teaching course}

In order to improve the quality of English Teaching, cultivate the talents of English skills and rich professional knowledge for a university, it is necessary to design an English teaching course reasonably, then to reform the English teaching mode, so as to meet the requirements of the demand 
angle. In the past, in the process of setting up the college English curriculum, usually based on general English, in spite that that has changed under the impact of the reform of the education system, but the result is not good. Therefore, in order to achieve the full reform of the curriculum, we must change to English for specific purpose, open more English courses, such as business English, English for specific purpose curriculum construction and others , and set up a interesting English course, so as to make up for the shortcomings of the low practical value of general English ${ }^{[4]}$. Under the background of economic globalization, in the process of college English teaching, colleges and universities must design English teaching courses reasonably, combine the general English with the specialized English courses, which can be integrated into other areas, and then to develop more complex and professional high-end English talents for the community.

\section{Innovation of English teaching mode}

From demand angle embarking, in order to improve the quality of English teaching, the university must make innovations in the teaching mode of English curriculum, so that students can not only learn rich professional knowledge, and stimulate their interest in learning English. For example, in the process of English reading teaching "How to write a personal letter" , the teacher allows the students to consult the unfamiliar vocabulary, such as immortal, otherwise and others, and use the self-learning pattern of the network to query this article, then appreciate it. Then the teacher analyzes the forepart content, shows the contents of we shy persons need to write a letter now and then, or else people will forget us.And I speak as one who prefers to reach for the phone, dial the number, and talk.The telephone is the easy way out for explaining and student reading. The main meaning of this article is that the first step to write is to overcome the guilt of not writing, and to write in their own way, even if you will make mistakes, be bold to write ${ }^{[5]}$. Through the innovation of English teaching mode, the interest of students in learning English has been improved obviously, and the students have acquired a wealth of English skills and professional knowledge to meet the needs of the society.

\section{Explicit teaching subject}

Demand analysis theory is an important way to master the students' English course. At present, more and more scholars have made the research on the middle school students' demand in College English teaching. by using the demand analysis theory as the guide, it can provide a favorable basis for the classroom teaching. Therefore, in the process of English course Teaching in colleges and universities, we must make the teaching subject clear, and enhance the students' subjective position. At the same time, in the teaching process, according to the actual needs of the teaching subject to adjust, and then break the consolidation teaching mode. Teaching should be set up through the situation, to make the teaching content diversified, so as to promote English teaching to achieve good results.

\section{Conclusions}

Under the background of the reform of the education system, the college English curriculum teaching must be innovative, so it needs to carry on demands analysis. Through the reasonable set of English curriculum, improving the teaching mode, and strengthening the teaching of English for special purpose, and promoting the students to master English skills and professional knowledge, who is the comprehensive top-level English talents, so as to meet the needs of society.

\section{References}

[1] He Lingxiao. In the term of demand, the reform trend of college English teaching.Journal of Lanzhou Institute of Education, 2010,26(6):129-131.

[2] Liu Zhenghui. In the term of student demand, the construction of multiple evaluation system of college English teaching-Lijiang College as an example. Journal of Simao Teachers' College,2012, 28(3):116-120 
[3] Yuan Jiali, Li Xiaohong. In the term of student demand, explore the new mode of college English teaching. Science and Technology Information, 2012(28):14.

[4] Shi Xiaojing. Demand analysis of the content setting of elective course of college English. Jiannan literature: Classics reading,2012(7):283-283,279.

[5] Zhu Xun. The course installation of college English based on learner needs analysis. Journal of Beijing Normal University (Social Science Edition), 2015 (1): 97-103 